\title{
Adoption and use of mobile banking by low-income individuals in Senegal
}

\author{
François Fall1, Luis Orozco ${ }^{*}$ and Akim Al-Mouksit2,3,4 \\ 1LEREPS, Université de Toulouse, UT2J \\ 21, allée de Brienne, 31042 Toulouse, France \\ ffall@univ-tlse2.f, luis.orozco@univ-tlse2.fr \\ *Corresponding author \\ ${ }_{2}$ World Bank, Washington DC, USA \\ 3IRD, LEDa, UMR [225], DIAL, 75016 Paris, France \\ 4CARDES, Ouagadougou, Burkina Faso \\ akim.al-mouksit@dauphine.eu
}

\begin{abstract}
The wide use of mobile phones is increasing low-income individuals' access to a large range of services. One of these services is mobile banking (m-banking). Today, mbanking represents a key vector of financial inclusion in many countries in Sub-Saharan Africa, especially in Senegal. Based on technology adoption theories applied to households in developing countries, this paper studies the determinants of the adoption and use of m-banking. We distinguish between possession or adoption from actual use of m-banking and examine the interdependence between these two decisions by using a Heckman sample selection model, through a sample of 1052 individuals in the suburbs of Dakar. Our main results are that the two decisions (adoption and use) are not independent from each other. Individual characteristics, such as education, possession of a bank account, and family network effects, are determinants of the adoption, and age, gender, and being a member of a tontine are determinants of the use. A major result of this study concerns women's low propensity to adopt m-banking because of their low levels of education. However, compared with men, when women adopt m-banking, they have a stronger propensity to use it.
\end{abstract}

JEL codes: C83, D14, O12, O33, O55

Key words: Mobile banking, mobile technologies, technology adoption, financial inclusion, individual characteristics, Senegal

\section{Acknowledgments:}

This article is part of a broader research project "The Impact of Mobile Banking on the wellbeing of Households" which has received funding from SIRCA of the Nanyang Technology University. We want to thank this structure and also, we thank the "Consortium for Economic and Social Research (CRES)" for the proofreading done on this document. An earlier version was presented at the AFSE meeting (French Economic Association) in 2016. We would like to thank the session chair and reviewers from the AFSE for their insightful comments and suggestions to improve this manuscript.

This is the pre-peer reviewed version of the following article: Fall FS, Orozco L, Akim A-M. Adoption and use of mobile banking by low-income individuals in Senegal. Rev Dev Econ. 2020;00:1-20, which has been published in final form at https://doi.org/10.1111/rode.12658. This article may be used for non-commercial purposes in accordance with Wiley Terms and Conditions for Use of Self-Archived Versions. 


\section{Introduction}

The rapid growth and adoption rate of mobile phones in developing countries, especially in Africa, has resulted in an exponential increase in mobile services (Aker, Boumnijel, Mcclelland, \& Tierney, 2016; Baptista \& Oliveira, 2016; Demirgüç-Kunt, Klapper, Singer, \& Van Oudheusden, 2015; Donner, 2008; Suri \& Jack, 2016; Van Der Boor, Oliveira, \& Veloso, 2014). Developing countries have experienced different diffusion paths of mobile phones, and mobile phones are considered a leapfrogging technology (Antonelli, 1991; James, 2009; Rama \& Wilkinson, 2013; Steinmueller, 2001). The adoption rate of mobile phones among the population in Sub-Saharan Africa in 2015 is $76.1 \%$ (99.9\% in Senegal), compared with 19\% of internet users $(21.7 \%)$ and $1 \%$ of fixed telephone subscriptions (2.2\%). 1 Additionally, approximately $14 \%$ of the population in Sub-Saharan Africa and 6\% of that in Senegal use mobile banking (m-banking). Formal accounts in financial institutions are held by $29 \%$ of the population in Sub-Saharan Africa, and the rate is $11.9 \%$ in Senegal2 (see figures 1 and 2 in the appendix).

The wide use of mobile phones is increasing low-income households' to access a large range of services (Aker et al., 2016; Mishra \& Bisht, 2013; Warren, 2007). One of these services is $\mathrm{m}$-banking. Today, $\mathrm{m}$-banking represents a key vector of financial inclusion in many countries in Sub-Saharan Africa (Baptista \& Oliveira, 2015; Chaix \& Torre, 2015; Fall, Ky, \& Birba, 2015; Jack \& Suri, 2014; Mishra \& Bisht, 2013; Shem, Odongo, \& Were, 2017). Academic research has just started to analyze the role of m-banking in today's economy. For example, there is no consensus in the definition of m-banking between the North and South. In industrialized countries, m-banking refers to an extension of banking and financial services provided on mobile phones by financial institutions (H. Lee, Harindranath, Oh, \& Kim, 2015; Shaikh, Karjaluoto, \& Chinje, 2015), By contrast, in developing countries, m-banking is a broader form of banking that includes, for example, payment services called m-payments (mobile remote payments), transfer of funds, and deposits (Fall et al., 2015; Jack \& Suri, 2011). In this paper, we define m-banking as a platform accessed by a mobile phone to make payments, transfer funds, make deposits (withdrawals are unnecessary), and borrow money (overdraft allowed).

\footnotetext{
1 This rapid expansion, which surpassed fixed-line subscriptions by 2002 , has been identified in the literature as the "fixed-to-mobile substitution" (Vogelsang, 2010). However, this substitution is mostly concerned with developed countries where fixed-lines subscriptions reached $50 \%$ of potential users (for high-income countries) by the year 2001 (S. Lee \& Marcu, 2011).

2 World Development Indicators, World Bank, 2014.
} 
In Senegal, as in many Sub-Saharan countries, mobile/telecom operators are the main driver of $\mathrm{m}$-banking. The most used m-banking service in Senegal is Orange Money, which is a product of Sonatel-Orange, the largest mobile operator in the country. Based on M-Pesa in Kenya, Orange Money is essentially dedicated to making payments, transferring funds, and charging phone credit but is increasingly concerned with financial services such as savings and credit. Orange Money is only available to customers of Orange, who can make deposits, withdrawals, and transfers with and between other Orange Money customers, and payments for services such telephones, water, and electricity.3 The other major m-banking platform is called Yoban'Tel, and it was introduced in 2010, sometime after Orange Money. However, this second platform was introduced by SGBS bank (Société Générale de Banques du Sénégal) in collaboration with CMS (Crédit Mutuel du Sénégal), one of the largest microfinance networks in the country, and Tigo, the second-largest mobile operator in Senegal. Unlike Orange Money, all customers can access this solution regardless of the mobile operator they use.4

This paper explores the determinants of the adoption and use of m-banking in Senegal and contributes to m-banking literature by filling some of its gaps. First, we investigate adoption as it relates to the difficulty of collecting detailed data on the adoption process. This difficulty is why most researchers have implicitly assumed that adoption refers to use. We distinguish between adoption (opening an m-banking account) from actual use (making payments, transfers, saving or borrowing money). Such differences have been studied in the ICT literature because the adoption and use of a new technology follow different patterns (Ghezzi, Rangone, \& Balocco, 2013; Goldfarb \& Prince, 2008; Lanzolla \& Suarez, 2012; Utterback \& Suarez, 1993). For instance, Lanzolla and Suarez (2012) argue that there is a delay between a technology's adoption and use.

Furthermore, Fall et al. (2015) explain that the adoption of an m-banking account does not necessarily mean it will be used for transactions. Individuals can adopt (install) the technology, because friends or family have suggested it, or because of the advertisement and promotions sent by the telecom/mobile operators. Once adopted, individuals do not necessarily use the technology (immediately) for several reasons: they do not have the funds to send/transfer/save

3 The broader the network of Orange is the greater the competitive advantage for Orange-Money is compared to its competitors.

4 In addition to these two main solutions, there are many other m-banking platforms, e.g., Wari, set up in 2009

by CSI (Cellular Systems International); Ferlo, an electronic banking platform set up in 2005; Gim Mobile; Joni; Tigo Cash; and Lamp Fall Cash. 
money (that is, to use it); they do not have the need to use it, or because they do not know how to use it. M-banking is in its early stages of development in Senegal, and most clients use it to take advantage of the underlying services such as promotions (from mobile operators), transfer funds with other people in the same network at a very low cost (clients, suppliers, family and friends).

In this sense, our aim is to extend the analysis of m-banking adoption by low-income individuals and to focus on m-banking use. Another limit of the m-banking literature is that the interdependence between the adoption and use decisions can produce biased results. Regarding this matter, are the adoption and use of m-banking decisions independent from each other? We argue that they are not and that the factors explaining the adoption and use of m-banking may differ. We propose that by isolating the selection bias between the two decisions, this paper advances the literature on m-banking adoption. We base our research on an original survey of mobile phone subscribers collected from low-income individuals in the suburbs of Dakar in 2012. We test the main determinants of adoption and use of m-banking by using a sample selection model with binary variables in both stages (Van de Ven \& Van Praag, 1981), adoption and use, which isolates the possible dependence between the two decisions.

The paper is organized as follows. Section 2 reviews the literature of m-banking as an instrument for financial inclusion, technology adoption theories, explanatory factors of $\mathrm{m}$ banking adoption and use, and the hypotheses. Section 3 describes the dataset, empirical model, and variables employed. The empirical findings are presented in Section 4. The last section concludes the paper and discusses its contributions.

\section{Literature review}

\subsection{Background on m-banking and financial inclusion}

The use of mobile phones for the provision of financial services has expanded dramatically in Senegal. With a coverage rate of more than $99.9 \%$ of the population, mobile phones have become an essential instrument in financial inclusion policies (De Koker \& Jentzsch, 2013; Demirgüç-Kunt et al., 2015; Shem, Misati, \& Njoroge, 2012; Shem et al., 2017). The success of this technology is most evident among low-income individuals, a large fraction of whom are excluded from traditional banking services and reside in rural or suburban areas. The contribution of m-banking to the dynamics of financial inclusion is both direct and indirect. Its 
direct contribution concerns the complementary role of this technology to existing financial inclusion programs. This is the case, for instance, of a retiree who resides in a remote rural area where there are no banking or microfinance agencies. With m-banking, they can receive their retirement pension on a mobile phone, through a simple transfer. As for the indirect contribution, this technology can be used by banks and microfinance institutions as a platform to expand their reach to a larger audience and diversify their financial products and services to low-income individuals.

\subsection{Technology adoption and use}

The adoption of new technology takes a considerable amount of time. The economic literature has focused on the inter- and intra-firm adoption of generic technologies, such as ICT, in which empirical studies, and stylized facts (Galliano \& Orozco, 2011; Galliano \& Roux, 2008; Geroski, 2000; Karshenas \& Stoneman, 1993; Rogers, 2003), have indicated that a new technology is adopted slowly at first but at an increasing rate over time, until a point of inflexion is reached, after which, the rate of growth declines. Furthermore, a time lapse occurs between the moment a firm adopts a new technology and the time it uses it (Goldfarb \& Prince, 2008; Lanzolla \& Suarez, 2012). In addition, adoption is a matter of degree. Some people adopt technology totally, by using it intensely, and others adopt it only marginally.

Several economic models have attempted to explain how the diffusion of technology takes place and why firms adopt technology at different stages. These models consist of the so-called "equilibrium" models (Battisti \& Stoneman, 2003; David, 1991; Karshenas \& Stoneman, 1993), the "epidemic" models (Mansfield, 1961, 1968), and the adoption models with "network externalities" (David, 1985; Farrell \& Saloner, 1985; Katz \& Shapiro, 1986).5 By contrast, several models have focused on the demand side or the consumer technology diffusion process (Battisti, 2008). This literature considers the spreading of consumer technology within and across households (Mahajan, Muller, \& Bass, 1990; Zettelmeyer \& Stoneman, 1993). However, as Battisti (2008) states, "consumer choice could be modeled following either the epidemic or the equilibrium approach" (Battisti, 2008, p. 28).

5 Also notable are the "informational cascades" models (Bikhchandani, Hirshleifer, \& Welch, 1998) and the unified theory of acceptance and use of technology (Baptista \& Oliveira, 2015; Min, Ji, \& Qu, 2008; Venkatesh, Morris, Davis, \& Davis, 2003). 
Equilibrium models. The equilibrium models (Battisti \& Stoneman, 2003; David, 1991; Karshenas \& Stoneman, 1993) are based on at least two of the following tenets of mainstream neoclassical theory: equilibrium, infinite rationality, and full information. This theory considers that the decision to adopt is the result of a cost-benefit calculation by potential adopters (firms or individuals) who anticipate the net benefits from adopting and using different technologies. These models are based on the hypothesis that information on the technology is known and shared and that the differences in the adoption levels between agents result from their heterogeneity. Battisti (2008) notes that the difference between firms and households is that the factors affecting the adoption of the latter are changes in, for example, preferences, information, prices, income, product performance, and lending and borrowing decisions.

Epidemic models. The second group of technology adoption models is the epidemic models (Mansfield, 1961, 1968), which emphasize the influence of information spillover effects on the diffusion of technology. A greater number of adopters indicates that there is a greater amount of information available on the technology and a higher diffusion rate of the information. The basic hypothesis is that information about a new technology takes time to reach all potential users (Geroski, 2000), and that the process requires both a common source of information and a word-of-mouth transmission process. 6

Network externalities. An additional set of models has been developed to explain the diffusion of technologies. Technology adoption models with "network externalities" have been well studied in the literature, especially for the adoption of competing technologies (David, 1985; Farrell \& Saloner, 1985; Katz \& Shapiro, 1986). Technology is characterized by network externalities that occur when the benefit an agent obtains from his adhesion to a network is positively correlated to the number of members connected to this network. In these types of models, users are heterogeneous, with different preferences for innovation, and they simultaneously decide whether to adopt or switch to a new technology or not. In the same context, the optimal decision may be for a firm to adopt a technology, simply because others have already done so, regardless of the information they have on the efficiency of such technology (Arthur, 1989).

\subsection{Adoption and use of m-banking}

6 An implicit hypothesis of this model, which is also one of their major shortcomings, is that once individuals acknowledge the technology, they will adopt it. 
The literature on m-banking in developing countries has to some extent neglected West African countries such as Senegal and focused more on Asia and leader countries such as Kenya (Baptista \& Oliveira, 2016; Jack \& Suri, 2014). In addition, most of the studies on m-banking have focused on the technical factors of the adoption (Hanafizadeh, Behboudi, Koshksaray, \& Tabar, 2014; K. C. Lee \& Chung, 2009; Mishra \& Bisht, 2013; Shaikh \& Karjaluoto, 2015) or on consumers' acceptance of the technology (Baptista \& Oliveira, 2015, 2016).

In Fall et al. (2015), they propose the adoption of m-banking as a three-step process: acquiring knowledge about the technology, possessing (or adopting) the technology, and using the technology. However, they do not consider the eventual selection bias between each decision. We can consider, such as in Goldfarb and Prince (2008), that different patterns and characteristics explain the individual adoption and use of a technology, and that there is a time lapse between the two decisions (Lanzolla \& Suarez, 2012). Several factors can explain the decision of an individual to adopt m-banking, that is, to open an account by using their mobile phone; however, this type of adoption does not mean that they will use this service for making payments or transfers, or to save or borrow money. If they do so, the use may occur for different reasons.

H1: The decisions to adopt and use m-banking are not independent from one another.

\subsubsection{Individuals' socioeconomic characteristics}

Mbiti and Weill (2016) identify age, level of education, standard of living, and household physical environment as determinants of m-banking adoption. Laforet and Li (2005), based on mobile and Internet banking adoption in China, demonstrate that users of m-banking and ebanking were mainly men. They also demonstrate that the level of education is not a key determinant for adoption. In their study, the users of mobile and internet banking were individuals aged older than 44 years. Among the users of internet banking, most were employees and executives, and among the users of m-banking, most were small-business owners. Their study, however, does not distinguish between adoption and actual usage. However, Chong (2013) finds that users with higher educational levels are more likely to use m-commerce 7 for transactions (e.g., m-payments and transferring money). Bankole et al. (2011) analyzes the adoption determinants of m-banking in Nigeria through a sample of 231

7 Similar to e-commerce but with transactions conducted on mobile devices (Chong, 2013). 
individuals and demonstrates that culture (using proxies, e.g., language, religion, and traditions) is the most important factor that influences the adoption behavior of m-banking. In Senegal, for example, individuals who do not speak French have more difficulty using mbanking (Fall et al., 2015).

Zins et Weill (2016) and Joshua and Koshy (2011) have found that the probability of adopting m-banking is lower among women compared with men. The low probability of women's adoption is generally because of their disadvantages compared with men in terms of access to education and employment (Novo-Corti, Varela-Candamio, \& García-Álvarez, 2014). Riquelme and Rios (2010) analyze the factors influencing the use of m-banking among ebanking users in Singapore, with gender as a moderator variable. They find a difference in the attitude between men and women regarding the use of m-banking. For instance, it is easier for women to use m-banking than men; however, this sample was biased in favor of people using internet banking.

H2: Women - because their levels of education and income are lower compared with men-in less-developed countries, are less likely to adopt m-banking compared with men. However, once women have adopted, they are more likely to use m-banking because of its great importance in small commerce transactions and women's management of their household's expenses.

Younger people are likely to adopt the technology, but because they are less responsible for the finances and responsibilities in their household, they are less inclined to use m-banking.

H3: Individuals' ages differently influence the adoption and use of m-banking. Younger generations are more likely to own m-banking technology but are less likely to use it.

\subsubsection{Network effects}

Having a bank account is not a prerequisite for adopting an m-banking account; however, several researchers have demonstrated that in Sub-Saharan Africa, most people with bank accounts also have m-banking accounts (Ky, Rugemintwari, \& Sauviat, 2016; Shem et al., 2012). M-banking could be considered a complementary service to exchange money or to transfer money to other members of their network, such as family members or business partners 
who do not have a bank account. Having an m-banking account allows individuals with regular bank accounts to access a new network of relationships. Notably, even passive users benefit from m-banking because they can take advantage of promotions (from the mobile operator) or transfer and receive funds with other people in the same network at a very low cost (Jack \& Suri, 2014). They can also receive micro-transfers of phone credits from family or friends belonging to the same m-banking network.

H4: Possessing a bank or a micro-financing account should benefit the adoption and use of mbanking.

H5: The probability of adopting and using an m-banking account increases with the number of family members using m-banking.

\subsubsection{Information sources for m-banking technology}

One factor less studied in the literature is the sources of information on m-banking. Mass media communication is a rapid, efficient means to diffuse information on the existence of new technology (Fourt \& Woodlock, 1960). In the case of m-banking, we expect potential users to acquire information on the technology mainly through mass media such as television. Additional information can reach potential users through advertisements or direct messages sent by the mobile/telecom operator to their subscribers. However, if we follow the epidemic models of technology diffusion, the word of mouth and the proximity to the source of information are vital to the adoption of new technology. Furthermore, information on new technology has a larger diffusion once the technology has been used by many individuals (Lanzolla \& Suarez, 2012). For instance, Brown and Venkatesh (2005) demonstrate that children have a strong influence on their family's decision to adopt new ICTs such as personal computers. In this context, we expect that the information sources that include friends and family networks, and concerts and tours, spread the word the best.

H6: The adoption of m-banking is strongly associated with access to information through wide supports such as television and concerts, and through family and friends.

\section{Data and methods}


In this section, we describe the data and variables. Next, we explain the methodological approach we use to consider the interdependence between the adoption and use decisions.

\subsection{Data and variables}

We use data from a household survey carried out in the suburbs of Dakar (Senegal) in 2012 by the Consortium for Economic and Social Research (CRES 8). A primary sample of 900 households was initially drawn from a census database of the National Agency of Statistics and Demography of Senegal (ANSD), by the method of quotas in the suburbs of Dakar. From this primary sample, households were selected between $10 \%$ above and $10 \%$ below the poverty line. Finally, the 400 households that fulfilled this criterion constituted the main sample. Within each household, information was collected on the head of the household and on all other members of the household. The information gathered focused on the characteristics of individuals and their relationship to m-banking. Particular attention was paid to the distinction between adoption and use. The final sample of our study comprised 1052 individuals.

\section{Dependent variables}

The adoption and use of m-banking are operationalized as follows: the adoption is a binary variable taking the value 1 if the person has opened/activated an m-banking account (with Orange Money or Yoban'Tel). The use is a binary variable taking the value 1 if the person uses its m-banking account to make payments, transfer funds, or save or borrow money.

\section{Independent and control variables}

Age and Gender are dummy variables with a value of 1 if an individual is under 45 years old, and 0 otherwise, and a value of 1 if the individual is a man, or 0 if a woman. Age allows us to determine whether the adoption and use behaviors vary according to the age of the individual. Notably, age very often does not have a linear relationship with technology adoption. The younger and older generations have different attitudes toward technology. We chose 45 years of age because the threshold is the turning point in adoption. The age distribution shows that adoption increases with age up to 45 years, and after that, it decreases.

${ }_{8}$ CRES is a research center created in 2004 by a group of researchers from various disciplines (e.g., economics, law, quantitative analysis, and sociology) from the Cheikh Anta Diop University of Dakar. For more http://www.cres-sn.org/ 
The network effects are operationalized through two types of variables. First, to capture whether a person belongs to other banking/savings networks, we use a dummy variable with value 1 if an individual possesses a bank or an MFI account and another dummy variable with value 1 if the individual belongs to a tontine (or ROSCA), and 0 otherwise. Second, to capture the network effect related to the use of m-banking by family members, we use the proportion of people with an m-banking account in the household.

To highlight the different sources of information from which individuals have learned about mbanking, we use a class variable with nine modalities, for example, mass media and messages received from the operator, family, and friends.

In addition, several controls are included. Family status is used to identify whether the person is married, single, or divorced/widowed. The variable number of jobs takes the value 1 if the individual has two or more jobs, and 0 if only one job is held. The number of years of education is a continuous variable taking values from 0 to 18 . Literacy and higher education are commonly associated with the adoption of mobile technologies such as m-banking (Brown, Cajee, Davies, \& Stroebel, 2003; Fall et al., 2015; Fungáčová \& Weill, 2015; Zins \& Weill, 2016). In addition, the theory of human capital (Becker, 1993) tells us that individuals with higher education also have higher revenues. Notably, because m-banking mostly manages small-value transactions, low-income individuals are more likely to use it, whereas high-income individuals are likely to use other means such as debit cards, wire transfers, and checks. We include a class variable with four modalities to capture the individual's income level.

Table 1 reports descriptive statistics for all variables.

[Insert table 1]

\subsection{Empirical model}

In this section, we outline the empirical analysis to test the determinants of adoption and use of m-banking. Fall et al. (2015) studied the sequential stages of acquiring knowledge and the possession and use of m-banking by applying a sequential logit model. However, they did not 
consider the eventual dependence between the different decisions. Riquelme and Rios (2010) also estimated the use of internet banking. This approach can lead to biased estimates because of the possible presence of selection bias. In this paper, we attempt to differentiate the adoption from the usage and consider the selection bias in the estimation of use by following Heckman (1979).

In what follows, we consider the choice to adopt an m-banking service to be dependent on the individuals' characteristics, the access to a network of , and the sources of information on technology. Once the individual chooses to adopt m-banking, he/she then chooses whether to use it.

The first part is a binary outcome equation that models the probability of adoption of mbanking. The probability of adopting m-banking, the selection equation, is defined as follows:

$$
S_{i *}^{*}=z^{\prime} \beta_{1}+u 1
$$

where

$$
S_{i} \begin{cases}1 & \text { if } S_{i}^{*}>0 \\ 0 & \text { otherwise }\end{cases}
$$

The binary decision $S_{i}$ to choose an m-banking account is modeled as the outcome of an unobserved latent variable $S_{i}^{*}$, and we observe that m-banking is adopted $\left(S_{i}=1\right)$ when $S_{i}^{*}>0$ . An assumption is that $S_{i}^{*}$ is a linear function of the exogenous covariates $z i$ and a random component $u_{1}$.

The second part uses a binary variable to model the use of m-banking, only in the case when $S_{i}=1$ (Van de Ven \& Van Praag, 1981). This equation represents the outcome equation and is expressed as

$$
Y_{i}=x_{i}{ }^{\prime} \beta_{2}+u 2
$$

where $Y_{i}$ is the m-banking usage choice, $x_{i}$ is a vector of exogenous explanatory variables, $u_{2}$ is a random component, and $\beta_{1}$ and $\beta_{2}$ are the parameters to be estimated. The error terms $u 1$ and $u 2$ are possibly correlated and assumed to be jointly distributed and homoscedastic: 


$$
\begin{gathered}
u_{1} \sim N(0, \sigma) \\
u_{2} \sim N(0,1) \\
\operatorname{corr}\left(u_{1}, u_{2}\right)=\rho
\end{gathered}
$$

We also impose exclusion restrictions, which require that the selection equation has at least one exogenous variable excluded from the use equation (Cameron \& Trivedi, 2010; Heckman, 1979). In our estimation, we use the source of information about m-banking because it should only influence the adoption and does not directly affect the use.

The parameters $\beta_{1}$ and $\beta_{2}$ are estimated by maximum likelihood estimation. The log likelihood, for observation $i$ is

$\ln L_{i}=\left\{\begin{array}{lr}\ln \Phi\left\{\frac{z_{i}^{\prime} \beta_{1}+\left(Y_{i}-x_{i}^{\prime} \beta_{2}\right)^{\rho} / \sigma}{\sqrt{1-\rho^{2}}}\right\}-\frac{1}{2}\left(\frac{Y_{i}-x_{i}^{\prime} \beta_{2}}{\sigma}\right)^{2}-\ln (\sqrt{2 \pi \sigma}) & \text { if } Y_{i} \text { is observed } \\ \ln \Phi\left(-z_{i}^{\prime} \beta_{1}\right) & \text { if } Y_{i} \text { is not observed }\end{array}\right.$

where $\Phi($.$) is the standard cumulative normal.$

Once a Chi2 test of the correlation coefficient $\rho$ is significantly different from zero, the null hypothesis is rejected, and we consider that the m-banking use equation is not independent from the selection equation (m-banking adoption). The two decisions are not made independently from one another; the Heckman selection model is thus justified.

\section{Findings}

Table 2 reports the results of the sample selection model with binary variables in both stages. The chi 2 test of the correlation coefficient $\rho$ indicates that it is significant and different from 0 at the $10 \%$ level (chi2 $(1)=3.43$ ). The result of this test suggests that the decision to use $\mathrm{m}$ banking is not independent from the decision to adopt an m-banking account. This result confirms our first hypothesis and highlights why this type of technique is essential when studying the factors that explain the adoption and the use of m-banking.

[Insert table 2] 
The adoption equation highlights the factors explaining the first step, namely, the selection equation. There is a positive relationship between the proportion of household members with an m-banking account and the likelihood of adopting one. The positive influence is significant at $1 \%$. Additionally, individuals who already have a financial account with a bank or MFI were more likely to have an m-banking account than those who do not have accounts at banks and MFIs. This influence is significant at $5 \%$. Some information channels are more effective than others in terms of informing individuals about m-banking. Individuals who have learned about m-banking through concerts, tours, or through $\mathrm{SMS}_{10}$ are more likely to own an m-banking account compared with those who obtained their information by watching television. This result highlights the active role of mobile/telecom operators in promoting and informing consumers about new services available for their mobile phones, and in this case, about m-banking. Their influence on the probability of individuals having m-banking accounts is significant at $1 \%$. In addition, individuals who have gained knowledge about m-banking through friends, neighbors, or family members have a higher probability of having m-banking accounts than those who learned about m-banking through television. The gender and age coefficients of adopters are not significant at this stage.

Regarding the control variables, we observe that the number of years of education has a positive and significant effect on the probability of adopting an m-banking account. In other words, the probability of having an m-banking account is higher as the years of education increase. Family status and the number of jobs are not significant.

Regarding the use of m-banking, the Heckman method allows us to correct the selection bias that concerns the individuals who adopted an m-banking account. These estimates show that sociodemographic characteristics and access to financial services are factors that increase the chances of using m-banking services. Additionally, we observe that, compared with men, women are more likely to use m-banking. Being a woman has a positive and significant influence on the use of m-banking (at the 5\% level). As aforementioned, women are less likely than men to adopt m-banking, but once they do, they are more likely to use it. This finding shows that adoption is a more informed choice for women than for men. Low adoption among women is also related to their low income level because having an m-banking account first requires having a mobile phone, which has a cost. Women's higher probability of use could 
also be explained by their greater involvement in income-generating activities. Women in the Sub-Saharan context are very present in commercial activities. The use of m-banking in this type of activity offers these women a substantial gain in time in transactions and allows them to secure the revenue generated by their activity. Indeed, women participating in trade can minimize the risk of theft, loss of money, and assault, because of payments through m-banking.

Age also does not maintain the same relationship with the two variables of interest, even if its influence on the adoption is not significant. Individuals aged over 45 years are also more likely to use m-banking than those aged below 45 years, and being older than 45 years old influences the use of m-banking at 5\%. This result is in line with those of Laforet and $\mathrm{Li}$ (2005). Younger generations are more likely to adopt m-banking technology, but those aged over 45 years are more likely to use it. These individuals are, essentially, those responsible for families and who own businesses, and they are likely to rely on this technology to optimize their spending or their productive activities.

The results also show that having an account at a bank or MFI increases the likelihood of using m-banking at the 5\% level. By contrast, participating in a tontine is associated with a negative probability of using m-banking. Having an account at a bank or MFI has the same influence on the adoption and use of m-banking. The result can be explained in two ways. First, the probability of adoption is higher among bank customers because they have a better financial education and therefore a better understanding of the services offered by m-banking. The second explanation is that bank customers use m-banking because this service complements the services provided by banks and microfinance institutions. Mbiti and Weil (2011) also demonstrate that m-banking is a complementary service to traditional banking services.

The number of years of study seems to have a positive relationship with m-banking adoption and use, except that its positive influence on the probability of use is not significant. This result still shows the importance of education in the possession and use of m-banking technology. This result is in line with those of Fall et al. (2015) and Zins and Weill (2016).

\section{Conclusion}

This paper attempts to identify the determinants of adoption and use of m-banking among lowincome individuals in the suburbs of Dakar. Considering that the adoption of m-banking is a process in which one can distinguish the adoption and use, this paper fills a gap in the literature 
by considering the selection bias between the two stages. Our results show that the decision to use m-banking is not independent of the decision to adopt an m-banking account, which confirms the selection bias. We can also compare the factors that determine the adoption of $\mathrm{m}$ banking technology and use of m-banking. The determinants of the use of m-banking are gender, age, possession of an account at a bank or MFI and participating in a tontine. Women have a higher propensity to use m-banking than men, which could suggest a greater degree of independence and empowerment for women in terms of their finances. The determinants of adoption, however, are the number of years of study, possessing an account in the bank or MFI, the proportion of people who have m-banking in the household, and that information about mbanking was gained at concerts or received through SMS by the mobile phone provider, friends, neighbors, and/or family members.

Based on some of our most significant results, we propose the following recommendations in terms of financial inclusion. Being a user of banking systems (i.e., bank or MFI customer) strongly promotes the adoption and use of m-banking. This variable is the only one that significantly influences adoption and use in the same direction. This reveals the usefulness of m-banking services for banking and microfinance clients. This result seems to indicate a complementarity between the banking and microfinance services and the m-banking services. This result is also observed because of the greater maturity of customers of the banking system, compared with those who are not mature. Such customers have a better understanding of mbanking services because their financial knowledge is higher than that of others, which explains their greater propensity to adopt the technology. Base on this result, we recommend greater integration of m-banking by banks and microfinance institutions. As Kumar et al. (2010) argue, the integration of m-banking by microfinance institutions can enable them to reach new geographical areas and improve the service they provide. We also encourage the promotion of financial education, to induce greater adoption of m-banking services. Financial education can lead individuals to make greater use of m-banking through a better understanding of the technology and its usefulness.

\section{References}

Aker, J. C., Boumnijel, R., Mcclelland, A., \& Tierney, N. (2016). Payment mechanisms and anti-poverty programs: evidence from a Mobile Money cash transfer experiment in Niger. Economic Development and Cultural Change, 65(1), 1-37. https://doi.org/10.1086/687578

Antonelli, C. (1991). The diffusion of advanced telecommunications in developing countries. OECD Development Centre.

Arthur, W. B. (1989). Competing technologies, increasing returns, and lock-in by historical 
events. Economic Journal, 99(394), 116-131. https://doi.org/10.2307/2234208

Bankole, F., Bankole, O., \& Brown, I. (2011). Mobile Banking adoption in Nigeria. The Electronic Journal on Information System in Developing Countries, 47(2), 1-23.

Baptista, G., \& Oliveira, T. (2015). Understanding mobile banking: The unified theory of acceptance and use of technology combined with cultural moderators. Computers in Human Behavior, 50, 418-430. https://doi.org/10.1016/j.chb.2015.04.024

Baptista, G., \& Oliveira, T. (2016). A weight and a meta-analysis on mobile banking acceptance research. Computers in Human Behavior, 63, 480-489. https://doi.org/10.1016/j.chb.2016.05.074

Battisti, G. (2008). Innovations and the economics of new technology spreading within and across users: gaps and way forward. Journal of Cleaner Production, 16(1), 22-31. https://doi.org/10.1016/j.jclepro.2006.06.007

Battisti, G., \& Stoneman, P. (2003). Inter- and intra-firm effects in the diffusion of new process technology. Research Policy, 32(9), 1641-1655. https://doi.org/10.1016/S00487333(03)00055-6

Becker, G. S. (1993). Human capital: a theoretical and empirical analysis, with special reference to education (3rd ed.). Chicago: University of Chicago Press.

Bikhchandani, S., Hirshleifer, D., \& Welch, I. (1998). Learning from the Behavior of Others: Conformity, Fads and Informational Cascades. Journal of Economic Perspectives, 12(3), 151-170. https://doi.org/10.1257/jep.12.3.151

Brown, I., Cajee, Z., Davies, D., \& Stroebel, S. (2003). Cell phone banking: Predictors of adoption in South Africa - An exploratory study. International Journal of Information Management, 23(5), 381-394. https://doi.org/10.1016/S0268-4012(03)00065-3

Brown, S., \& Venkatesh, V. (2005). Model of adoption of technology in households: A baseline model test and extension incorporating household life cycle. MIS Quarterly, 29(3), 399-426. https://doi.org/10.2307/25148690

Cameron, A. C., \& Trivedi, P. K. (2010). Microeconometrics using Stata (Revised Ed). College Station, Texas: Stata Press.

Chaix, L., \& Torre, D. (2015). Le double rôle du paiement mobile dans les pays en développement. Revue économique, 66(4), 703-727. https://doi.org/10.3917/reco.664.0703

Chong, A. Y. L. (2013). Mobile commerce usage activities: The roles of demographic and motivation variables. Technological Forecasting and Social Change, 80(7), 1350-1359. https://doi.org/10.1016/j.techfore.2012.12.011

David, P. (1985). Clio and the Economics of QWERTY. American Economic Review, 75(2), 332.

David, P. (1991). Behind the Diffusion Curve. Oxford: Westview Press.

De Koker, L., \& Jentzsch, N. (2013). Financial Inclusion and Financial Integrity: Aligned Incentives? World Development, 44, 267-280. https://doi.org/10.1016/j.worlddev.2012.11.002

Demirgüç-Kunt, A., Klapper, L., Singer, D., \& Van Oudheusden, P. (2015). The Global Findex Database 2014: Measuring Financial Inclusion around the World. World Bank Policy Research Working Paper 7255, (April), 1-88. https://doi.org/10.1596/1813-94507255

Donner, J. (2008). Research approaches to mobile use in the developing world: A review of the literature. The Information Society, 24(3), 140-159. 
https://doi.org/10.1080/01972240802019970

Fall, F. S., Ky, Y., \& Birba, O. (2015). Analyzing the Mobile-Banking Adoption Process among Low-Income Populations: A Sequential Logit Model. Economics Bulletin, 35(4), 2085-2103.

Farrell, J., \& Saloner, G. (1985). Standardization, compatibility, and innovation. RAND Journal of Economics, 16(1), 70-83. https://doi.org/10.2307/2555589

Fourt, L. A., \& Woodlock, J. W. (1960). Early prediction of market success for new grocery products. The Journal of Marketing, 25(2), 31-38. https://doi.org/10.2307/1248608

Fungáčová, Z., \& Weill, L. (2015). Understanding financial inclusion in China. China Economic Review, 34, 196-206. https://doi.org/10.1016/J.CHIECO.2014.12.004

Galliano, D., \& Orozco, L. (2011). The determinants of electronic traceability adoption: a firm-level analysis of French agribusiness. Agribusiness, 27(3), 379-397. https://doi.org/10.1002/agr.20272

Galliano, D., \& Roux, P. (2008). Organisational motives and spatial effects in Internet adoption and intensity of use: evidence from French industrial firms. The Annals of Regional Science, 42(2), 425-448. https://doi.org/10.1007/s00168-007-0157-z

Geroski, P. A. (2000). Models of technology diffusion. Research Policy, 29(4-5), 603-625. https://doi.org/10.1016/S0048-7333(99)00092-X

Ghezzi, A., Rangone, A., \& Balocco, R. (2013). Technology diffusion theory revisited: a regulation, environment, strategy, technology model for technology activation analysis of mobile ICT. Technology Analysis \& Strategic Management, 25(10), 1223-1249. https://doi.org/10.1080/09537325.2013.843657

Goldfarb, A., \& Prince, J. (2008). Internet adoption and usage patterns are different: Implications for the digital divide. Information Economics and Policy, 20(1), 2-15. https://doi.org/10.1016/j.infoecopol.2007.05.001

Hanafizadeh, P., Behboudi, M., Koshksaray, A. A., \& Tabar, M. J. S. (2014). Mobile-banking adoption by Iranian bank clients. Telematics and Informatics, 31(1), 62-78. https://doi.org/https://doi.org/10.1016/j.tele.2012.11.001

Heckman, J. J. (1979). Sample Selection Bias as a Specification Error. Econometrica, 47(1), 153-161. https://doi.org/10.2307/1912352

Jack, W., \& Suri, T. (2011). Mobile Money: The Economics of M-Pesa. NBER Working Paper Series, 1-30. https://doi.org/10.1017/CBO9781107415324.004

Jack, W., \& Suri, T. (2014). Risk sharing and transactions costs: Evidence from Kenya's mobile money revolution. American Economic Review, 104(1), 183-223. https://doi.org/10.1257/aer.104.1.183

James, J. (2009). Leapfrogging in mobile telephony: A measure for comparing country performance. Technological Forecasting and Social Change, 76(7), 991-998. https://doi.org/10.1016/j.techfore.2008.09.002

Joshua, A. J., \& Koshy, M. P. (2011). Usage patterns of electronic banking services by urban educated customers: glimpses from India. Journal of Internet Banking and Commerce, 16(1), 1-12.

Karshenas, M., \& Stoneman, P. L. (1993). Rank, stock, order, and epidemic Effects in the diffusion of new process technologies: an empirical model. The RAND Journal of Economics, 24(4), 503-528. https://doi.org/10.2307/2555742

Katz, M. L., \& Shapiro, C. (1986). Technology adoption in the presence of network externalities. Journal of Political Economy, 94(4), 822-841. 
https://doi.org/https://doi.org/10.1086/261409

Kumar, K., McKay, C., \& Rotman, S. (2010). Microfinance and mobile banking : the story so far (CGAP focus note, World Bank No. 62). Washington, DC. Retrieved from http://documents.worldbank.org/curated/en/131111468324554756/Microfinance-andmobile-banking-the-story-so-far

Ky, S., Rugemintwari, C., \& Sauviat, A. (2016). Does Mobile Money affect saving behavior? Evidence from a developing country. SSRN Working Paper. https://doi.org/10.2139/ssrn.2815090

Laforet, S., \& Li, X. (2005). Consumers' attitudes towards online and mobile banking in China. International Journal of Bank Marketing, 23(5), 362-380. https://doi.org/10.1108/02652320510629250

Lanzolla, G., \& Suarez, F. F. (2012). Closing the Technology Adoption-Use Divide: The Role of Contiguous User Bandwagon. Journal of Management, 38(3), 836-859. https://doi.org/10.1177/0149206310369938

Lee, H., Harindranath, G., Oh, S., \& Kim, D. J. (2015). Provision of mobile banking services from an actor-network perspective: Implications for convergence and standardization. Technological Forecasting and Social Change, 90(PB), 551-561. https://doi.org/10.1016/j.techfore.2014.02.007

Lee, K. C., \& Chung, N. (2009). Understanding factors affecting trust in and satisfaction with mobile banking in Korea: A modified DeLone and McLean's model perspective.

Interacting with Computers, 21(5-6), 385-392. https://doi.org/10.1016/j.intcom.2009.06.004

Lee, S., \& Marcu, M. (2011). An empirical analysis of fixed and mobile broadband diffusion. Information Economics and Policy, 23(3-4), 227-233. https://doi.org/10.1016/j.infoecopol.2011.05.001

Mahajan, V., Muller, E., \& Bass, F. (1990). New product diffusion models in marketing: a review and directions for research. The Journal of Marketing, 54(1), 1-26. https://doi.org/10.2307/1252170

Mansfield, E. (1961). Technical change and the rate of imitation. Econometrica, 29(4), 741766. https://doi.org/10.2307/1911817

Mansfield, E. (1968). Industrial Research and Technological Innovation: An Econometric Analysis. RS Means Company.

Mbiti, I., \& Weil, D. N. (2016). Mobile Banking: The impact of M-Pesa in Kenya. In S. Edwards, S. Johnson, \& D. N. Weil (Eds.), African Successes, Volume III: Modernization and Development (pp. 247-293). Chicago: University of Chicago Press. https://doi.org/10.3386/w17129

Min, Q., Ji, S., \& Qu, G. (2008). Mobile Commerce User Acceptance Study in China: A Revised UTAUT Model. Tsinghua Science and Technology, 13(3), 257-264. https://doi.org/10.1016/S1007-0214(08)70042-7

Mishra, V., \& Bisht, S. (2013). Mobile banking in a developing economy: A customer-centric model for policy formulation. Telecommunications Policy, 37(6), 503-514. https://doi.org/https://doi.org/10.1016/j.telpol.2012.10.004

Novo-Corti, I., Varela-Candamio, L., \& García-Álvarez, M. T. (2014). Breaking the walls of social exclusion of women rural by means of ICTs: The case of 'digital divides' in Galician. Computers in Human Behavior, 30, 497-507. https://doi.org/10.1016/J.CHB.2013.06.017

Rama, R., \& Wilkinson, J. (2013). ICT adoption and diffusion patterns in Latin American 
agriculture. In Information and communication technologies for agricultural development in Latin America: trends, barriers and policies (pp. 49-76). Santiago: ECLAC. Retrieved from http://repositorio.cepal.org/handle/11362/35437

Riquelme, H. E., \& Rios, R. E. (2010). The moderating effect of gender in the adoption of mobile banking. International Journal of Bank Marketing, 28(5), 328-341. https://doi.org/10.1108/02652321011064872

Rogers, E. M. (2003). Diffusion of Innovations (5th ed.). New York: Free Press.

Shaikh, A. A., \& Karjaluoto, H. (2015). Mobile banking adoption: A literature review. Telematics and Informatics, 32(1), 129-142. https://doi.org/10.1016/j.tele.2014.05.003

Shaikh, A. A., Karjaluoto, H., \& Chinje, N. B. (2015). Continuous mobile banking usage and relationship commitment - A multi-country assessment. Journal of Financial Services Marketing, 20(3), 208-219. https://doi.org/10.1057/fsm.2015.14

Shem, A. O., Misati, R., \& Njoroge, L. (2012). Factors driving usage of financial services from different financial access strands in Kenya. Savings and Development, 36(1), 7189.

Shem, A. O., Odongo, T. M., \& Were, M. (2017). Mobile financial services and financial inclusion: Is it a boon for savings mobilization? Review of Development Finance, 7(1), 29-35. https://doi.org/10.1016/j.rdf.2017.01.001

Steinmueller, W. E. (2001). ICTs and the possibilities for leapfrogging by developing countries. International Labour Review, 140(2), 193-210. https://doi.org/10.1111/j.1564913X.2001.tb00220.x

Suri, T., \& Jack, W. (2016). The long-run poverty and gender impacts of mobile money. Science, 354(6317), 4-9. https://doi.org/10.1126/science.aah5309

Utterback, J., \& Suarez, F. (1993). Innovation, competition, and industry structure. Research Policy, 22(1), 1-21. https://doi.org/doi: 10.1016/0048-7333(93)90030-1

Van de Ven, W. P. M. M., \& Van Praag, B. (1981). The demand for deductibles in private health insurance: A probit model with sample selection. Journal of Econometrics, 17(2), 229-252. https://doi.org/10.1016/0304-4076(81)90028-2

Van Der Boor, P., Oliveira, P., \& Veloso, F. (2014). Users as innovators in developing countries: The global sources of innovation and diffusion in mobile banking services. Research Policy, 43(9), 1594-1607. https://doi.org/10.1016/j.respol.2014.05.003

Venkatesh, V., Morris, M., Davis, G., \& Davis, F. (2003). User Acceptance of Information Technology: Toward a Unified View. MIS Quarterly, 27(3), 425-478. https://doi.org/10.2307/30036540

Vogelsang, I. (2010). The relationship between mobile and fixed-line communications: A survey. Information Economics and Policy, 22(1), 4-17. https://doi.org/10.1016/j.infoecopol.2009.12.002

Warren, M. (2007). The digital vicious cycle: Links between social disadvantage and digital exclusion in rural areas. Telecommunications Policy, 31(6), 374-388. https://doi.org/https://doi.org/10.1016/j.telpol.2007.04.001

Zettelmeyer, F., \& Stoneman, P. (1993). Testing alternative Models of New Product Diffusion. Economies of Innovation and New Technology, 2, 283-308. https://doi.org/https://doi.org/10.1080/10438599300000009

Zins, A., \& Weill, L. (2016). The determinants of financial inclusion in Africa. Review of Development Finance, 6(1), 46-57. https://doi.org/10.1016/J.RDF.2016.05.001 
Table 1: Descriptive statistics

\begin{tabular}{|c|c|c|c|c|c|c|}
\hline Variable & Measurement & Obs & Mean & $\mathrm{Sd}$ & Min & Max \\
\hline $\begin{array}{l}\text { Adoption of m- } \\
\text { manking }\end{array}$ & $\begin{array}{l}\text { A binary variable taking } 1 \text { value if the person } \\
\text { has an Orange Money account or Yoban'Tel } \\
\text { account or both and } 0 \text { otherwise }\end{array}$ & 1052 & 0,06 & 0,24 & 0 & 1 \\
\hline Use of m-banking & $\begin{array}{l}\text { A binary variable taking } 1 \text { value if the person } \\
\text { uses its account (Orange Money account or } \\
\text { Yoban'Tel account or both) and } 0 \text { otherwise }\end{array}$ & 1052 & 0,04 & 0,19 & 0 & 1 \\
\hline $\begin{array}{l}\text { Age }=\text { less than } 45 \\
\text { years old }\end{array}$ & $\begin{array}{l}\text { A binary variable taking } 1 \text { value if the person is } \\
\text { less that } 45 \text { years old and } 0 \text { otherwise }\end{array}$ & 1052 & 0,29 & 0,45 & 0 & 1 \\
\hline Female & $\begin{array}{l}\text { A binary variable taking } 1 \text { value if the person is } \\
\text { female and } 0 \text { if male }\end{array}$ & 1052 & 0,58 & 0,49 & 0 & 1 \\
\hline $\begin{array}{l}\text { Account in a bank or } \\
\text { an MFI }\end{array}$ & $\begin{array}{l}\text { A binary variable taking } 1 \text { value if the person } \\
\text { has an account in a bank or microfinance } \\
\text { institution }\end{array}$ & 1052 & 0,39 & 0,49 & 0 & 1 \\
\hline Tontine & $\begin{array}{l}\text { A binary variable taking } 1 \text { value if the person } \\
\text { belongs to a ROSCA and } 0 \text { otherwise }\end{array}$ & 1052 & 0,21 & 0,40 & 0 & 1 \\
\hline $\begin{array}{l}\text { Proportion of people } \\
\text { with m-banking } \\
\text { account in the } \\
\text { household }\end{array}$ & $\begin{array}{l}\text { Ratio of number of people in the household } \\
\text { having a m-banking account by the size of } \\
\text { household }\end{array}$ & 1052 & 0,04 & 0,12 & 0 & 1 \\
\hline TV & $\begin{array}{l}\text { A binary variable taking } 1 \text { value if the person } \\
\text { has known Orange Money or Yoban Tel by TV } \\
\text { and } 0 \text { otherwise }\end{array}$ & 1052 & 0,66 & 0,47 & 0 & 1 \\
\hline Radio & $\begin{array}{l}\text { A binary variable taking } 1 \text { value if the person } \\
\text { has known Orange Money or Yoban Tel by } \\
\text { Radio and } 0 \text { otherwise }\end{array}$ & 1052 & 0,06 & 0,24 & 0 & 1 \\
\hline Newspaper & $\begin{array}{l}\text { A binary variable taking } 1 \text { value if the person } \\
\text { has known Orange Money or Yoban Tel by } \\
\text { newspapers and } 0 \text { otherwise }\end{array}$ & 1052 & 0,02 & 0,14 & 0 & 1 \\
\hline Posters & $\begin{array}{l}\text { A binary variable taking } 1 \text { value if the person } \\
\text { has known Orange Money or Yoban Tel by } \\
\text { posters and } 0 \text { otherwise }\end{array}$ & 1052 & 0,02 & 0,13 & 0 & 1 \\
\hline Podium and concert & $\begin{array}{l}\text { A binary variable taking } 1 \text { value if the person } \\
\text { has known Orange Money or Yoban Tel by } \\
\text { Podiums and concerts and } 0 \text { otherwise }\end{array}$ & 1052 & 0,08 & 0,27 & 0 & 1 \\
\hline $\begin{array}{l}\text { SMS received from } \\
\text { Orange or Tigo }\end{array}$ & $\begin{array}{l}\text { A binary variable taking } 1 \text { value if the person } \\
\text { has known Orange Money or Yoban Tel by sms } \\
\text { received from Orange or Tigo and } 0 \text { otherwise }\end{array}$ & 1052 & 0,08 & 0,27 & 0 & 1 \\
\hline By family member & $\begin{array}{l}\text { A binary variable taking } 1 \text { value if the person } \\
\text { has known Orange Money or Yoban Tel by a } \\
\text { member of the family and } 0 \text { otherwise }\end{array}$ & 1052 & 0,02 & 0,14 & 0 & 1 \\
\hline $\begin{array}{l}\text { By friends or } \\
\text { neighbors }\end{array}$ & $\begin{array}{l}\text { A binary variable taking } 1 \text { value if the person } \\
\text { has known Orange Money or Yoban Tel by } \\
\text { friends or neighbors and } 0 \text { otherwise }\end{array}$ & 1052 & 0,05 & 0,22 & 0 & 1 \\
\hline Other & $\begin{array}{l}\text { A binary variable taking } 1 \text { value if the person } \\
\text { has known Orange Money or Yoban Tel by } \\
\text { other channels and } 0 \text { otherwise }\end{array}$ & 1052 & 0,01 & 0,09 & 0 & 1 \\
\hline Married & $\begin{array}{l}\text { A binary variable taking } 1 \text { value if the person is } \\
\text { married and } 0 \text { otherwise }\end{array}$ & 1052 & 0,60 & 0,49 & 0 & 1 \\
\hline Single & $\begin{array}{l}\text { A binary variable taking } 1 \text { value if the person is } \\
\text { single and } 0 \text { otherwise }\end{array}$ & 1052 & 0,32 & 0,47 & 0 & 1 \\
\hline
\end{tabular}


Widowed/divorced

Two jobs or more

Years of education

Income less than

50,000

Income less than 50,000 and 100,000

Income less than 100,000 and 300,000

Income higher than 300,000
A binary variable taking 1 value if the person is windowed/divorced and 0 otherwise

A binary variable taking 1 value if the person has two jobs or more only and 0 otherwise

Number of years of education

A binary variable taking 1 value if the income is less than 50000 FCFAa and 0 otherwise

A binary variable taking 1 value if the income is between 50000 FCFA and 100000 FCFA and 0 otherwise

A binary variable taking 1 value if the income is between 100000 FCFA and 300000 FCFA and 0 otherwise

A binary variable taking 1 value if the income is higher 300000 FCFA and 0 otherwise

$\begin{array}{lllll}1052 & 0,08 & 0,27 & 0 & 1 \\ 1052 & 0,02 & 0,15 & 0 & 1 \\ 1052 & 8,13 & 5,30 & 0 & 18 \\ 1052 & 0,35 & 0,48 & 0 & 1 \\ 1052 & 0,36 & 0,48 & 0 & 1 \\ & & & & \\ 1052 & 0,27 & 0,44 & 0 & 1 \\ & & & & \\ 1052 & 0,03 & 0,17 & 0 & 1\end{array}$

${ }_{\mathrm{a}} \mathrm{FCFA}=$ Franc CFA (Financial Community of Africa). 1 EUR $=655.957$ FCFA. 
Table 2: Results of the two-step adoption and use of mobile banking

\begin{tabular}{|c|c|c|c|c|}
\hline & \multicolumn{2}{|c|}{$\begin{array}{c}\text { Selection equation } \\
\text { Adoption of m-banking }\end{array}$} & \multicolumn{2}{|c|}{$\begin{array}{l}\text { Outcome equation } \\
\text { Use of m-banking }\end{array}$} \\
\hline & Coef. & Std. & Coef. & Std. \\
\hline \multicolumn{5}{|l|}{ Gender $($ Ref $=$ Male $)$} \\
\hline Female & -0.202 & $(0.221)$ & $0.278 * *$ & $(0.118)$ \\
\hline \multicolumn{5}{|l|}{ Age $(\operatorname{Ref}=$ more than $45 y o)$} \\
\hline Age $=$ less than 45 yo & 0.198 & $(0.204)$ & $-0.310 * *$ & $(0.130)$ \\
\hline \multicolumn{5}{|l|}{ Account in a bank or an MFI $(\operatorname{Ref}=n o)$} \\
\hline Account in a bank or an MFI $=$ Yes & $0.529 * * *$ & $(0.198)$ & $0.289 *$ & $(0.149)$ \\
\hline \multicolumn{5}{|l|}{ Tontine $(\operatorname{Ref}=\mathrm{No})$} \\
\hline Tontine $=$ Yes & 0.265 & $(0.251)$ & $-0.425 * *$ & $(0.166)$ \\
\hline $\begin{array}{l}\text { Proportion of people with } \mathrm{m} \text {-banking account in } \\
\text { the household }\end{array}$ & $8.409 * * *$ & $(0.962)$ & -0.351 & $(0.342)$ \\
\hline \multicolumn{5}{|l|}{ Source of information about m-banking $(\operatorname{Ref}=\mathrm{TV})$} \\
\hline Radio & 0.527 & $(0.351)$ & & \\
\hline Newspapers & $-6.381 * * *$ & $(0.337)$ & & \\
\hline Posters & -0.139 & $(1.052)$ & & \\
\hline Concerts & $1.332 * * *$ & $(0.277)$ & & \\
\hline Via SMS received form operator & $0.951 * * *$ & $(0.330)$ & & \\
\hline Family member & $0.823^{*}$ & $(0.421)$ & & \\
\hline Friends or neighbors & $1.401 * * *$ & $(0.276)$ & & \\
\hline Other & 0.538 & $(0.487)$ & & \\
\hline \multicolumn{5}{|l|}{ Family status $($ Ref=married $)$} \\
\hline Single & -0.187 & $(0.229)$ & 0.257 & $(0.156)$ \\
\hline Widowed/divorced & 0.294 & $(0.320)$ & 0.175 & $(0.263)$ \\
\hline Number of years of education & $0.0638 * * *$ & $(0.018)$ & 0.00932 & $(0.010)$ \\
\hline \multicolumn{5}{|l|}{ Number of jobs $($ Ref $=$ one $)$} \\
\hline Two or more & 0.324 & $(0.370)$ & 0.0207 & $(0.241)$ \\
\hline \multicolumn{5}{|l|}{ Income (Ref=less than 50000 FCFAa) } \\
\hline Income $=50000-100000$ & 0.157 & $(0.259)$ & 0.0385 & $(0.147)$ \\
\hline Income $=100000-300000$ & -0.280 & $(0.324)$ & -0.261 & $(0.162)$ \\
\hline Income $=300000$ et plus & $-0.874 *$ & $(0.515)$ & 0.0309 & $(0.341)$ \\
\hline Constant & $-3.830 * * *$ & $(0.416)$ & $0.865^{* * *}$ & $(0.267)$ \\
\hline LR test of independent eqns. $($ rho $=0)$ & $\operatorname{chi} 2(1)=3.43^{*}$ & & & \\
\hline Censored observations & 986 & & & \\
\hline Uncensored observations & 66 & & & \\
\hline lambda & $-0.26 * *$ & $(0.12)$ & & \\
\hline
\end{tabular}

Robust standard errors in parentheses

$* p<0.10, * * p<0.05, * * * p<0.01$

${ }_{\mathrm{a}} \mathrm{FCFA}=$ Franc CFA (Financial Community of Africa). 1 EUR $=655.957$ FCFA. 


\section{Appendix}

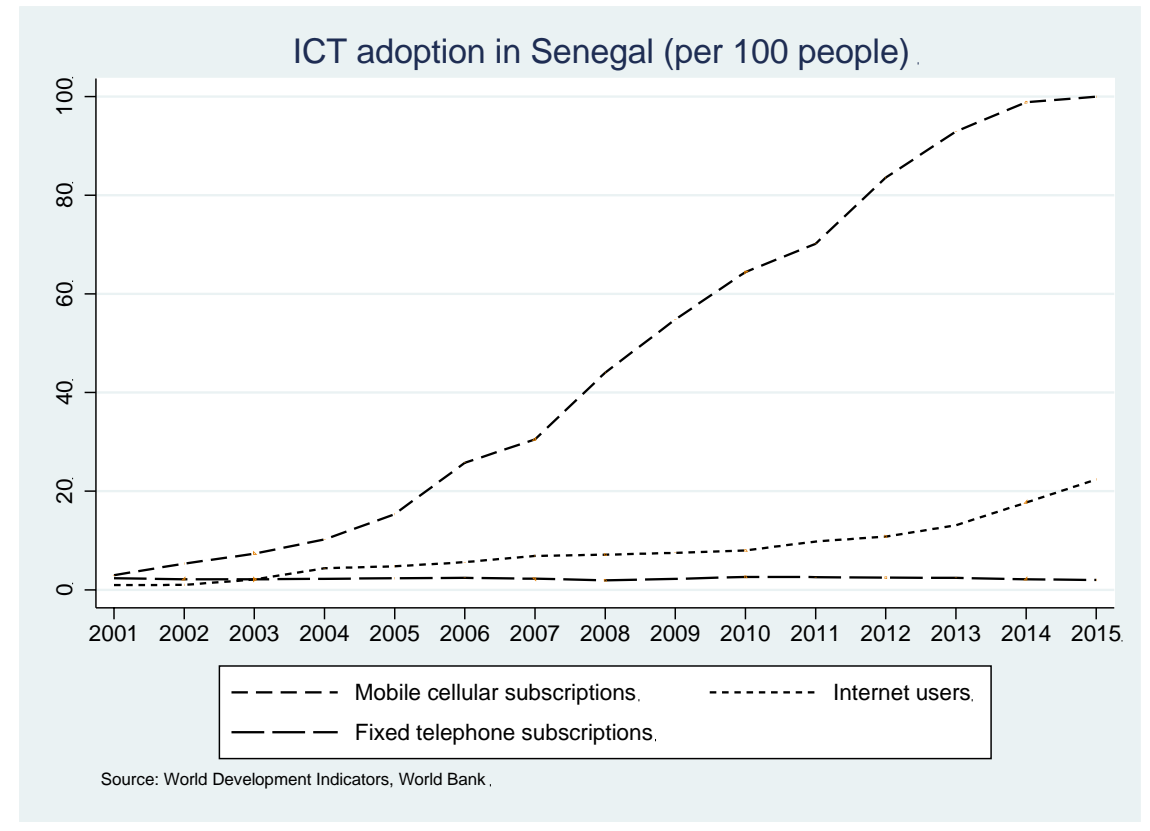

Figure A1: ICT adoption in Senegal

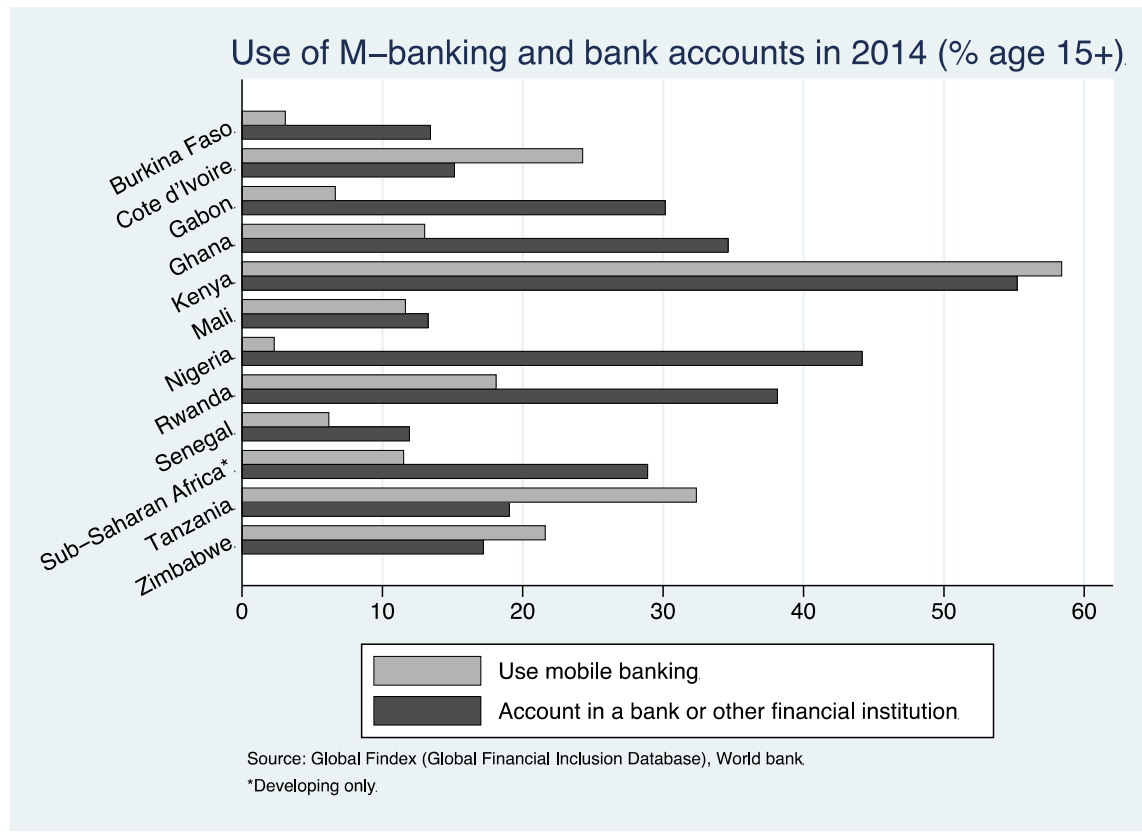

Figure A2: Use of m-banking and bank accounts 